\title{
РЕЦЕНЗІЯ НА МОНОГРАФІЮ: ГОРПІНІЧ Т. І. ТЕОРЕТИЧНІ ЗАСАДИ ПРОФЕСІЙНОЇ ПІДГОТОВКИ МАЙБУТНІХ ЛІКАРІВ В УНІВЕРСИТЕТАХ США / Т. І. ГОРПІНІЧ ; НАУК. РЕД. А. В. ВИХРУЩ. - ТЕРНОПІЛЬ : ТДМУ, 2018. - 408 с.
}

Одним із пріоритетних завдань підготовки майбутніх лікарів на сучасному етапі становлення системи вищої освіти є розвиток творчих здібностей, готовності до самостійної постановки проблем, їх розв’язання, творчого осмислення здобутого досвіду з подальшим використанням його в нових професійних ситуаціях. Медицина належить до тих галузей людського знання, у яких зазначені якості відіграють особливу роль. Саме тому дедалі гостріше постає проблема якісної професійної підготовки майбутнього лікаря. Один з імовірних шляхів її розв’язання полягає у вивченні зарубіжного досвіду підготовки медичних працівників, зокрема досвіду США, які за останні десятиріччя досягли значних успіхів у модернізації своєї освітньої системи та чиї вищі медичні навчальні заклади довели свій високий статус і справедливо вважаються взірцевими в галузі медицини. У зв’язку з цим дослідження Т. І. Горпініч своєчасне та актуальне.

У першому розділі монографії “Історико-теоретичний аналіз системи професійної підготовки майбутніх лікарів в університетах США” здійснено ретроспективний аналіз становлення і розвитку професійної медичної освіти у США. Авторка обгрунтувала необхідність вивчення професійного досвіду США у галузі вищої медичної освіти та адаптації певних передових ідей до вітчизняних реалій при входженні України до світового освітнього простору. Тетяна Ігорівна Горпініч закцентувала увагу на теоретичних засадах й практичному досвіді (методи, прийоми, технології) в освітніх закладах медичного профілю США, адже підвищення якості медичної освіти пов’язане з потребою у висококваліфікованих спеціалістах, які мають бути підготовленими до відповідальної професійної діяльності, подальшого неперервного навчання в умовах сучасної економіки та світової інтеграції.

Авторка схарактеризувала зміст, форми, методи організації підготовки медиків у США. Відтак T. I. Горпініч проаналізувала основні тенденції та модернізаційні процеси у підготовці майбутніх лікарів, вивчила нормативні документи та робочі програми, питання особливостей відбору студентів у вищі медичні навчальні заклади США, критерії та стандарти оцінювання вступних іспитів студентів.

У другому розділі монографії “Управління системою медичної освіти США” авторка звернула особливу увагу на досягнення США в галузі управління якістю вищої медичної освіти, де протягом десятиліть розробляється і реалізується ідея орієнтації всіх ланок освіти на людину та її потреби, а саме: парадигмальні підстави управління; системність і збалансованість управління з позицій повноважень його суб’єктів, функцій, що реалізуються ними; системні підстави управління (циклічність, відповідність принципам взаємодії компонентів); результативність, ефективність управління в соціальному, економічному, педагогічному та організаційному вимірах.

Науковець довела, що якість підготовки лікарів у США залежить від нерозривного зв' язку, взаємодії та співпраці державних, професійних і соціальних суб’єктів вищої освіти. Авторка дослідила вплив досвіду США на професійну підготовку майбутніх лікарів інших країн у контексті формування їх творчих здібностей, розглянула основні напрями реформування системи вищої медичної освіти США, у контексті яких відбувається формування творчої особистості студентів медичного профілю, проаналізувала стратегії, методи та прийоми, спрямовані на розвиток творчих здібностей студентів-медиків.

У третьому розділі “Сучасна університетська освіта США як педагогічне середовище підготовки фахівців медичного профілю” на основі комплексного аналізу досвіду США щодо формування особистості студента медичного профілю дослідниця виокремила такі здобутки систем вищої медичної освіти цієї країни: надання студентам можливості вивчати предмети за вибором, брати участь у різноманітних програмах, конкурсах на отримання грантів, винагород, які студенти можуть використати на навчання за кордоном, на проведення науково-дослідних робіт; застосування методів навчання, що активізують розумові здібності студентів, мотивують до пізнання, творчої діяльності; широкий вибір темпів навчання, цілей, методів, 
навчального матеріалу, вимог до рівня успішності; застосування технології індивідуалізованого навчання з усіх предметів від мінімальної модифікації в процесі групового навчання до незалежного навчання; використання передових досягнень освіти, науки і техніки, залучення потужних інвестицій в науково-освітню сферу.

Авторка ретельно дослідила сутність та специфіку професії лікаря у США, проаналізувала особливості організації професійної підготовки лікарів на додипломному етапі навчання, виокремила особливості організації післядипломного етапу підготовки лікарів у США, а відтак наголосила на творчому підході до формування особистості майбутнього фахівця з акцентом на дидактичних основах викладацької діяльності у вищих навчальних закладах медичного профілю в США.

У четвертому розділі “Організація професійної підготовки студентів” Т. І. Горпініч висвітлила питання компетентнісного підходу в підготовці лікарів у медичних закладах США, адже в американській педагогічній науці компетентність $є$ центральним, вихідним і визначальним поняттям, яке об’ єднує інтелектуальний і практичний складники, де закладена ідеологія інтерпретації змісту освіти, зорієнтована на результат, й має інтегративну природу (містить однорідні чи споріднені уміння і знання, що належать до широких сфер культури і діяльності (інформаційної, медичної тощо)).

Водночас авторка проаналізувала питання професійної придатності медичного працівника, коли центральним поняттям професійного розвитку $є$ професійні цінності та установки, які визначають професійну поведінку та професійну придатність медичного працівника, його здатність діяти в професійній сфері відповідно до свого світогляду. 3'ясовано, що цьому сприяють налагоджена система організації позааудиторних форм роботи, зосередження на проблемах полікультурного навчального середовища, гуманізація форм роботи 3 іноземними студентами.

Беззаперечним $є$ наукова новизна і теоретичне значення дослідження, які викладені в запропонованій монографії. Вони полягають у тому, що вперше було системно досліджено засади професійної підготовки лікарів у вищих медичних школах США; виявлено та обгрунтовано етапи становлення і розвитку медичної професійної освіти у США; визначено особливості професійного відбору та зарахування абітурієнтів до медичних закладів; уточнено теоретичну сутність поняття та специфіку професії лікаря в системі охорони здоров’я США.

Монографія призначена для студентів, аспірантів та усіх, хто цікавиться історією професійної підготовки майбутніх лікарів в університетах США.

Професор кафедри педагогіки початкової освіти Прикарпатського національного університету імені Василя Стефаника доктор педагогічних наук, професор

Г. В. Білавич 